\title{
Management of Rheumatic Heart Diseases in Burundi
}

\author{
E. Ndirahisha ${ }^{1}$, E. Baransaka ${ }^{1}$, J. Nyandwi ${ }^{1}$, H. Bukuru ${ }^{1}$, \\ C. Muserebanyi ${ }^{1}$, M. Nimburanira ${ }^{2}$, R. Nyandwi ${ }^{1}$ \\ ${ }^{1}$ University of Burundi, Faculty of Medicine, Bujumbura, Burundi \\ ${ }^{2}$ Military Hospital of Kamenge, Service of Cardiology, Bujumbura, Burundi
}

\begin{abstract}
Background: The surgical management of rheumatic heart disease (RHD) in Burundi is almost impossible because of the absence of the technical plateau. Aim: To describe the therapeutic and evolutionary aspects of RHD in Burundi. Patients and methods: This is a retrospective and analytical study of patients' records in surgical indication and/or operated for RHD by facilitation of "Maison du Bon Samaritain du Burundi (MBSB)" from February 2015 to February 2017. Results: Among 89 patients consulting for RHD, $45(50.56 \%)$ were operated. The average age of the patients was 25 years. Females predominated with $64.04 \%$ of cases. The age of most of patients was between 4 and 40 years with 74 cases $(83.14 \%)$. All patients had been received at the heart failure stage including $83(93.25 \%)$ at stage III or IV according to the New York Heart Association (NYHA) classification. The ejection fraction was $\leq 50 \%$ in 61 patients (68.53\%). Pulmonary arterial hypertension was recorded in 79 patients $(88.76 \%)$. On chest X-ray, cardiomegaly was found in 85 patients $(95.50 \%)$. Electrical abnormalities were dominated by dilatation of the left atrium in 48 cases (53.93\%). Isolated valvular lesions were the most numerous with 67 cases (75.28\%). The operative management was mainly valvular replacement $(93.47 \%)$ with an operative success of $100 \%$ six months after the intervention. Conclusion: The diagnosis of RHD was late. Young people were more vulnerable. The postoperative prognosis at six months was good.
\end{abstract}

Key words: Rheumatic heart disease, Valvulopathy, Prognosis, Burundi

Correspondence author: Eugene Ndirahisha, MD, Teacher Researcher of Cardiovascular diseases, University of Burundi, Faculty of Medicine, Department of Internal Medicine, Bujumbura, Burundi

E-mail: kabandeugene@yahoo.fr

Ndirahisha E. 000-0003-3243-1967

Baransaka E. 0000-0002-7796-6626

Nyandwi J. 0000-0002-3715-7891

Bukuru H. 0000-0001-7961-8097

Nyandwi R. 0000-0003-4371-425X

For citation: Ndirahisha E., Baransaka E., Nyandwi J., Bukuru H., Muserebanyi C., Nimburanira M., Nyandwi R. Management of Rheumatic Heart Diseases in Burundi. RUDN Journal of Medicine, 23 (3), 290-296. DOI: 10.22363/2313-0245-2019-233-290-296.

Для цитирования: Ндирахиша Е., Барансака Е., Няндви Дж., Бкулу Х., Мусеребаньи С., Нимбуранира М., Няндви Р. Ревматические пороки сердца в Бурунди // Вестник Российского университета дружбы народов. Серия: Медицина. 2019. T. 23. No 3. C. 290 -296. DOI: $10.22363 / 2313-0245-2019-23-3-290-296$. 


\section{Introduction}

The surgical management of rheumatic heart disease (RHD) in Burundi is almost impossible because of the absence of the technical plateau. In "The VALVAFRIC study: a registry of rheumatic heart disease in Western and Central Africa" published in "Arch. Cardiovasc. In 2016", S. Kingué et al. [1] found that patients with RHD hospitalized in sub-Saharan Africa were young, socially deprived, with a high mortality rate and very little chance of accessing surgical care. The prevalence of rheumatic heart disease, estimated mainly from surveys of schoolchildren, ranged from 2.7/1000 in Kenya to 14.3/1000 in Congo Brazzaville [2, 3]. S. Kingué et al. found a prevalence of RHD estimated at $12.3 \%$ and a hospital mortality of $16 \%$ [1].

In Burundi, no literature mentions the surgical management of RHD. In that order, we found necessary to check out this affection with the aim to specify, at a short-term, therapeutic and outcome aspects of rheumatic valvulopathies in Burundi.

\section{Patients and methods}

This is a retrospective and analytical study of patients operated and/or waiting surgical intervention for RHD. Those patients are followed up by cardiologists from February 2015 to February 2017. The study was initiated during a workshop of Burundi' cardiologist association. As we did not have statistical data of what was already done, this study was done with the aim of implementing a database and using it later as advocacy with non-governmental organizations and sister societies of cardiology. Whenever a cardiologist diagnosed a heart condition requiring surgery, he established a patient record that included disease history and data examination with a Doppler echocardiography report, a chest Xray, an HIV serology, and a blood count. Then he sent the file to the "MBSB" to prepare the administrative file and transfer of the patient. Whenever the patient was accepted, further care was provided by cardiovascular surgeons from abroad (Sudan, France, Egypt and Italy).
All patients with an indication for surgery and/or already operated were included in the study. The diagnostic criteria for RHD were clinical (presence of a heart murmur and/or signs of heart failure) and ultrasound (valvular remodeling with calcification and/or retraction of the cords resulting in leakage or stenosis).

The surgical indication was posed according to the recommendations of the European Society of Cardiology [4]. We have retained for mitral stenosis an area less than $1.5 \mathrm{~cm}^{2}$ in symptomatic patients. For asymptomatic patients, surgery was indicated when the risk of thromboembolism or haemodynamics was high (atrial fibrillation, pulmonary arterial hypertension). For mitral insufficiency, surgery was indicated for left ventricular dysfunction with ejection fraction $\leq 50 \%$. For an aortic stenosis, surgery was indicated in front of a valvular area $<1 \mathrm{~cm}^{2}$. For a symptomatic or asymptomatic aortic insufficiency, surgery was indicated if the left ventricular telesystolic diameter was $>50 \mathrm{~mm}$. Pulmonary arterial hypertension (PAH) was defined as Systolic Pulmonary Arterial Pressure (SPAP) greater than $60 \mathrm{mmHg}$ and was a contraindication. Chest $\mathrm{X}$-ray and electrocardiogram were used as a cardiopulmonary resonance assessment.

The collection of data was carried out using a data sheet established for this purpose. The data were demographic (age, sex, marital status), socioeconomic (occupation, level of education, housing and means of travel), cardiac history, data from clinical and para-clinical examinations. In this study, according to the Burundi 2016-2017 demographic survey [5], poverty or poor socioeconomic status was defined by lack of drinking water (tap water), housing where people are exposed to smoke, housing with electric lighting, television set or radio, financial resources, durable goods in the household and inaccessibility to health care. The analysis and the computer processing of the data were carried out by the software Epi Info v.

This study was approved by the Research and health ethic committee (in French: Comité d'éthique 
et de recherche en santé humaine), an institutional committee of bio-ethic of the "Centre hospitalo-universitaire de Kamenge et de la faculté de medicine de l'université du Burundi', in accordance with the code of ethics for biomedical research involving human subjects. Data were collected and treated anonymously. As a retrospective study, the consent to publish the results and patients data was obtained from the bio-ethic committee.

\section{Results}

Among 219 patients with heart disease awaiting surgery at the MBSB, 89 patients had RHD, $40.63 \%$ of cases.Women predominated with a sex ratio (M/F) of 0.56 . All patients in the study lived in poverty.

The average age was 25 years with extremes of 4 and 64 years. The modal class was the age group under 20 years with $42.69 \%$. The main reasons for consultation were NYHA dyspnea stage III or IV with 83 cases $(93.25 \%)$, palpitations in 61 patients $(68.53 \%)$ and lower extremity edema in 43 patients (48.31\%). The physical examination revealed tachyarrhythmia in 23 patients $(25.84 \%)$, bradycardia in two patients $(2.24 \%)$ and heart murmurs indicating mitral involvement in $41(46.06 \%)$ and aortic in $13(14.60 \%)$. The brilliancy of B2 in the pulmonary focus was found in 79 patients $(88.76 \%)$. A clinical picture of heart failure was present in all patients, including 79 cases $(88.76 \%)$ of congestive heart failure and $10(11.23 \%)$ of left heart failure.
Chest X-ray revealed cardiomegaly in 83 patients $(93.25 \%)$ with a cardiothoracic ratio greater than 0.60. The 12-lead electrocardiographic pattern recorded and left atrial dilatation in 48 patients (53.93\%) each. Complete arrhythmia with atrial fibrillation was recorded in 23 patients $(25.84 \%)$. First-degree atrioventricular block and sinus bradycardia were each observed in two patients (2.24\%).

Echocardiography revealed valvular changes that were responsible forvalvular stenosis and insufficiency. Isolated valvular lesion was recorded in 67 patients $(75.28 \%)$ and polyvalvulopathy in 22 patients $(24.71 \%)$. The systolic function of the left ventricle was impaired with an ejection fraction of less than $50 \%$ in all patients. It was less than $35 \%$ in three patients (3.37\%). Systolic pulmonary arterial hypertension greater than $60 \mathrm{mmHg}$ was recorded in 79 patients $(88.76 \%)$.

The operation was performed abroad for all patients. The countries of intervention were Sudan, France, Egypt and Italy with respectively 36 cases (78.26\%), 8 cases $(17.39 \%)$ and one case $(2.17 \%)$ for the two last. Forty-six patients $(51.68 \%)$ underwent surgery including 43 cases of (93.47\%) valve replacement and three cases (6.52\%) of valve repair. Among the 43 remaining patients, 14 (15.73\%) were waiting for intervention, $17(19.10 \%)$ were no operable, $4(4.49 \%)$ refused to be operated, $1(1.12 \%)$ disappeared and $7(7.86 \%)$ died before intervention.

Distribution of patients on age and valvular lesions $(N=89)$

Таблица 1

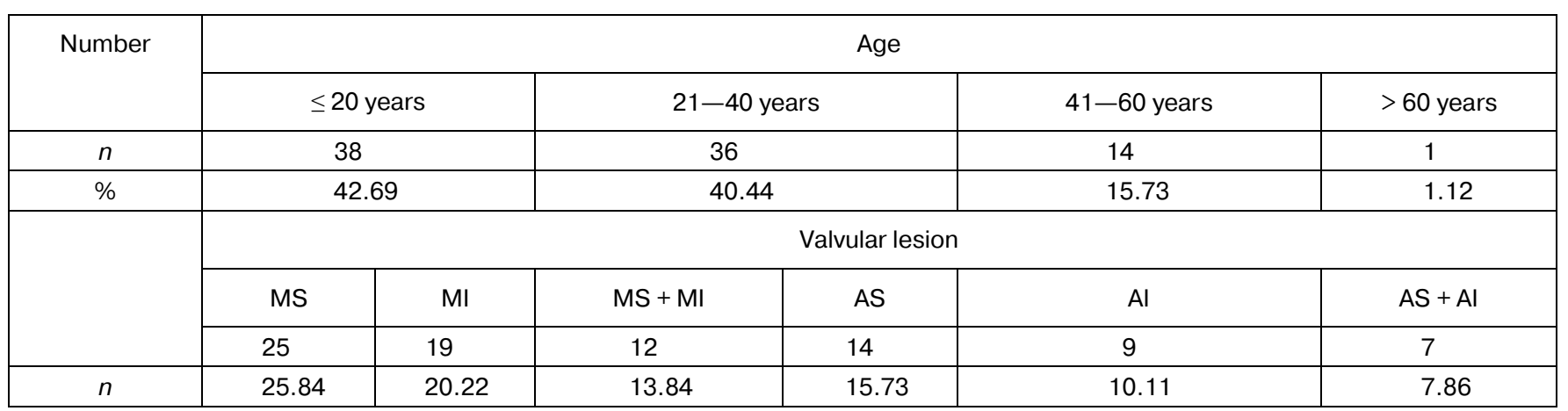


Per operative management was hygieno-dietary and medicated. Thirty-one patients $(67.39 \%)$ were on diuretics and $28(60.86 \%)$ on antibiotics. Nineteen patients $(41.30 \%)$ were on beta-blockers. Forty-one patients $(95.34 \%)$, among the 43 carriers of mechanical prostheses, were on antivitamin K (AVK). Two of them (4.87\%) were able to do the international normalized ratio (INR) regularly once a month. The complete disappearance of signs of exercise intolerance was observed in 43 patients (93.47\%). No deaths were observed up to six months postoperatively. Seven cases of death were observed before the intervention by cardiovascular collapse on a failing heart.

\section{Discussion}

In Burundi, the surgical management of rheumatic heart disease (RHD) is almost impossible because of the absence of the technical plateau. According to the "REMEDY" study published in "European Heart Journal" in 2015, RHD occupies one of the first places of non-communicable diseases and would be responsible for 1.4 million deaths per year [6].

In our study, RHD accounted for $40.60 \%$ of cardiac affections with surgical indication. The patients were young with an average age of 25 years and $42.69 \%$ were 20 years old or younger. This situation has been described previously by other authors. S. Kingué et al. [1], found an RHD frequency of $12.3 \%$ and an average age of 29.1 years for men and 31.1 years for women. L. Zühlke et al., in the REMEDY study [6], found a median age of 28 years. J.B.T. Somnoma et al. [7], in their study on child heart disease at Suro Sanou University Hospital in Bobo-Dioulasso in 2016, found 14\% of cardiopathies for surgical indication. A predominance of women had already been observed by others in SubSaharan Africa and outside the continent. S. Kingué et al. [1], L. Zühlke [6], Goeh A.E. et al. [8], and C.N. Manjunath et al. [9] found a female predominance with respectively $60 \%, 66.2 \%, 66 \%$ and $67.27 \%$ of cases. J.R. Carapetis [10], in his work on rheumatic heart disease in developing countries published in the "New England Journal of Medicine" in 2007; made an observation that rheumatic heart disease was linked to poverty. In ourstudy, all patients came from poor areas.

Clinically, the interview was not a contributor to information on the history of rheumatic fever because patients did not remember or realize they had been sick in their past. The main reasons for consultation were dyspnea stage III to IV in 83 patients (93.25\%) according to the NYHA classification, palpitations in $61(68.53 \%)$ and lower extremity edema in 43 (48.31\%). The cardiovascular physical examination revealed tachyarrhythmia in 23 patients (25.84\%) and a picture of heart failure in all patients. This situation could be explained by late management, poor treatment adherence and inaccessibility to quality care for our poor population. A.E. Goeh et al. [8], gave the same explanation.

The chest $x$-ray showed cardiomegaly in 83 cases (93.25\%). K. Diao et al. [11], in their 2005 study on rheumatic heart disease in Dakar, found cardiomegaly in $82.2 \%$ of cases. In our study, electrical abnormalities were dominated by left atrial dilatation (OG) with 48 cases (53.93\%). Complete atrial fibrillation (AF) arrhythmia was recorded in $25.84 \%$ of patients. According to R. Slama et al. [12], in their book on rhythmology in 2003 in Paris, FA is rarely permanent if the diameter of the left atrium is less than $45 \mathrm{~mm}$. On the other hand, almost all the patients whose diameter of the left atrium at the echocardiography is greater than $55 \mathrm{~mm}$ are in permanent atrium's fibrillation [12].

In our study, echocardiography noted the clear predominance of monovalvular disease with 67 cases (75.28\%). Among the monovalvular lesions, the mitral valve was the most affected in $62.92 \%$ of cases. The polyvalvulopathy accounted for $24.72 \%$ of the cases. J. Mucumbitsi, in his study Cardiac surgery for advanced rheumatoid disease in Rwanda, found $18 \%$ of polyvalvulopathy [13]. The ejection fraction was less than $50 \%$ in 61 (68.54\%) patients. According to L. Zühlke et al. [6], more than $25 \%$ had left ventricular dysfunction. This shows the severity of the disease at the time of management. 
Therapeutically, all patients received health and dietary advice. Medical treatment was recommended for all patients while awaiting evacuation abroad where surgical treatment was possible. Since this situation is common to many countries in sub-Saharan Africa, some authors propose a federation of means for regional management [7].

The European Society of Cardiology and the European Association of Cardio-Thoracic Surgery in 2012 recommend valve replacement when valve retention is impossible or when there is another surgical valve injury [14]. In our study, 43/46 operated (93.47\%) had valvular replacement and 3 (6.52\%) had valvular repair. This means that these patients were operated at a late stage when valve retention was already impossible. All cases of valvular insufficiency were treated with valve replacement. According to P.M. Barsoum et al. [15], in their 2015 study on the prognosis of valvular interventions among indigenous populations in New Caledonia, a major mitral leak exacerbated by dyspnea or pulmonary sub-œdema is subject to replacement of the valve. In the same way, the surgical intervention is obligatory in case of atrium's fibrillation.

Postoperative follow-up was marked by a systematic prescription of an anticoagulant except in three patients who had undergone valvular repair. Indeed, according to J.R. Carapetis et al. [16] in their study entitled "The global burden of group A streptococcal diseases", anyone who has undergone mechanical heart valve replacement surgery must be put on anticoagulant all his life. In our series, 41 (95.34\%) of the 43 patients with prostheses received a prescription of AVK but only $2(4.34 \%)$ were able to regularly perform the INR of control.

C.M. Vassileva et al. [17], in their study "Longterm survival of patients undergoing a mitral valve repair and replacement: a longitudinal analysis of Medicare fee-for-service beneficiaries", found that postoperative mortality depended largely on disease. We did not register any postoperative deaths. This could be explained by a rigorous selection by the team of surgeons who rejected the cases deemed inoperable.
Six months after the procedure, 43 patients (93.48\%) completely recovered with disappearance of functional signs and gain of systolic and diastolic functions on echocardiography. Three patients $(6.52 \%)$ improved. Seven recorded deaths from cardiovascular collapse were still waiting for a surgical operation.

\section{Conclusion}

Rheumatic heart disease is common in our country. It represents $40.60 \%$ of the cardiopathies in surgical indication in our study. The extent of the lesions is a sign of late diagnosis in a young population. For this reason the majority of patients $(93.47 \%)$ underwent valve replacement. The short-term postoperative prognosis is good. An extension of the prevention of rheumatic fever would be a salvation for our population and at the same time avoid the stage of inoperability of some of them.

\section{Conflicts of interest}

The authors do not declare any conflict of interest.

\section{Authors' Contributions}

All authors contributed to the writing of this manuscript. All authors read and approved the final manuscript.

\section{Study financing}

The study was initiated during a workshop of Burundi' cardiologist association; and then the authors have taken advantage to meet and come up with this topic which was done with their own means.

\section{References}

1. Kingué S., Ba S.A., Baldé D., Diarra M.A., AnzouaKacou J.B., Anisubia B. et al. The VALVAFRIC study: A registry of rheumatic heart disease in Western and Central Africa. Arch. Cardiovasc. Dis. 2016; 109: 321-29.

2. Essop M.R., Nkomo V.T. Rheumatic and no rheumatic valvular heart disease: epidemiology, management, and prevention in Africa. Circulation 2005; 12: 3584-40.

3. Kimbally-Kaky G., Gombet T., VoumboY., Ikama-Méo S., Elenga-Mbola B., Mbika-Cardorelle A. et al. Rheumatic heart disease in schoolchildren in Brazzaville. Med Trop. 2008; 68: 603-5.

4. Guidelines on the management of valvular heart disease (version 2012). The joint task Force on the Management of Valvular Heart Disease of the European Society of Cardiology (ESC) and the European Association for Cardiothoracic surgery (EACTS). European Heart Journal. 2012; 33: 2451—96. 
5. République du Burundi. Troisièmeenquête démographiqueet de santé 2016-2017. The DHS Program, ICF, Rockville, Mary Land, USA. 2017: 9-13.

6. Zühlke L., Engel M.E., Kurthikeyan G., Rangarajan S, Cupido M.B.P., Mauff K. et al. Characteristics, complications, and gaps in evidence-based interventions in rheumatic heart disease: the Global Rheumatic Heart Disease Registry (the REMEDY study). European Heart Journal. 2015; 36 (18): 1115-32.

7. Somnoma J.B.T., Senkaye L.A.K., Yaméogo A.A., Yaméogo N.B. Les cardiopathies de l'enfant au CHU SouroSanou de Bobo-Dioulasso: aspects échographiques et thérapeutiques. Med d'Afr Noire. 2016; 9 (5/6): 1—4.

8. Goeh A.E., Gbeasor F.D., Baragou S., Damorou F., Gbadoe A.D., Kessie K., AtakoumaDy, Soussou B.L. Les cardiopathiesrhumatismales au Centre Hospitalier Universitaire Tokoin de Lomé. Rev CAMES, Série A, Vol. 06, 2008:12-7.

9. Manjunath C.N., Srinivas P., Ravindranath K.S., Dhanalakshmi C. Incidence and patterns of valvular heart disease in a tertiary care high-volume cardiac center: A single center experience. Indian Heart J. 2014; 66(3): $320-6$.

10. Carapetis J.R. Rheumatic heart disease in developing countries. N Engl J Med. 2007; 357-441.

11. Diao K., Kane A., Doumbia A., Leye M.M., Mbaye A., Kane A. et al. Cardiopathiesrhumatismalesévolutives à propos de 17 cascolligés au CHU de Dakar. Med trop. 2005 (65): 339.

12. Slama R., Motté G., Leenhardt A., Sebag C. Aide-mémoire de rythmologie. 2ième Edition; Flammarion Médecine-Sciences; Paris. 2003: 112-30.

13. Mucumbitsi J. Cardiac surgery for advanced rheumatic disease in Rwanda. Cardiovasc J Afr. 2016; 27(3): $184-7$.

14. Guidelines on the management of valvular heart disease (version 2012). The Joint Task Force on the Management of Valvular Heart Disease of the European Society of Cardiology (ESC) and the European Association for CardioThoracic Surgery (EACTS). Eur Heart J; 2012 (33), 2451-96.

15. Barsoum P.M., Mirabel M., Iung X.J.B., Marijon E., Patricia R. Pronostic des interventions valvulairesparmi les populations autochtonesen Nouvelle Calédonie. Circulation. 2015; 13 (15): 10249.

16. Carapetis J.R., Steer A.C., Mulholland E.K., Weber M. The global burden of group A streptococcal diseases. Lancet Infect Dis. 2005; 5(11):685 94.

17. Vassileva C.M., Mishkel G., Neely C.M., Boley T., Markwell S., Scaife S. et al. Long-term survival of patients undergoing mitral valve repair and replacement: a longitudinal analysis of Medicare fee-for-service beneficiaries. Circulation. 2013; 127(18): 1870—6

(C) Ndirahisha E., Baransaka E., Nyandwi J., Bukuru H., Muserebanyi C., Nimburanira M., Nyandwi R., 2019 This work is licensed under a Creative Commons Attribution 4.0 International License

Received 26.07.2019

Accepted 13.09.2019

DOI: $10.22363 / 2313-0245-2019-23-3-290-296$

\title{
Ревматические пороки сердца в Бурунди
}

\author{
Е. Ндирахиша ${ }^{1}$, Е. Барансака ${ }^{1}$, Дж. Няндви ${ }^{1}$, Х. Бкулу ${ }^{1}$, \\ С. Мусеребаньи ${ }^{1}$ М. Нимбуранира ${ }^{2}$, Р. Няндви ${ }^{1}$ \\ ${ }^{1}$ Университет Бурунди, медицинский факультет, Бужумбура, Бурунди \\ ${ }^{2}$ Военный госпиталь Каменге, Служба кардиологии, Бужумбура, Бурунди
}

Справочная информация. Хирургическое лечение ревматических заболеваний сердца (БРВ) в Бурунди практически невозможно из-за отсутствия технического оснащения. Цель: описать терапевтические и эволюционные аспекты RHD в Бурунди. Пациенты и методы. Это ретроспективное и аналитическое исследование истории болезни пациентов с показаниями к хирургическому вмешательству и/или оперированными по поводу RHD при содействии "Maison du Bon Samaritain du Burundi (MBSB)" с февраля 2015 года по февраль 2017 года. Результаты. Из 89 пациентов, обращавшихся за РГС, 45 $(50,56 \%)$ были оперированы. Средний возраст пациентов составил 25 лет. Женщины преобладали в 64,04\% случаев. 
Возраст большинства пациентов составлял от 4 до 40 лет (74 случая $(83,14 \%))$. Все пациенты были приняты на стадии сердечной недостаточности, включая $83(93,25 \%)$ на стадии III или IV в соответствии с классификацией Нью-Йоркской кардиологической ассоциации (NYHA). Фракция выброса составила $\leq 50 \%$ у 61 пациента (68,53\%). Легочная артериальная гипертензия зафиксирована у 79 пациентов $(88,76 \%)$. На рентгенограмме грудной клетки кардиомегалия была обнаружена у 85 пациентов (95,50\%). Электрические нарушения были обусловлены дилатацией левого предсердия в 48 случаях $(53,93 \%)$. Изолированные клапанные поражения были самыми многочисленными - 67 случаев $(75,28 \%)$. Оперативное лечение состояло в основном из клапанной замены $(93,47 \%)$ с успешным оперативным вмешательством $100 \%$ через шесть месяцев после операции. Заключение: диагноз RHD был поздно поставлен. Молодые люди находятся в зоне риска. Прогноз после операции через шесть месяцев был хорошим.

Ключевые слова: ревматическая болезнь сердца, вальвулопатия, прогноз, Бурунди

Ответственный за переписку: Евгений Ндирахиша, доктор медицинских наук, преподаватель-исследователь сердечнососудистых заболеваний, Университет Бурунди, медицинский факультет, факультет внутренних болезней, Бужумбура, Бурунди. E-mail: kabandeugene@yahoo.fr

(C) Ндирахиша Е., Барансака Е., Няндви Дж., Бкулу Х., Мусеребаньи С., Нимбуранира М., Няндви Р., 2019 This work is licensed under a Creative Commons Attribution 4.0 International License

Поступила 26.07.2019 Принята 13.09.2019 